\title{
Effects Of Sunlight Exposure For Treatment Of Tuberculosis : Literature Review
}

\author{
Liza Novitasari Wijaya, Sri Nabawiyati Nurul Makiyah \\ Universitas Muhammadiyah Yogyakarta, Indonesia \\ Corresponding author: lizawijaya94@gmail.com
}

\begin{abstract}
Background: Tuberculosis is a contagious infectious disease caused by Mycobacterium. Tuberculosis which can attack various organs, especially the lungs. It is necessary to study the effectiveness of sunlight therapy and the vitamin D diet as supporting tuberculosis treatment.

Purpose: This study aimed at investigating the literature for of provision of sunlight in tuberculosis patients.

Methods: This library review uses a database with the electronic search on Ebsco, ClinicalKey, Google Scholar, and ScienceDirect published in 2016 - 2019.

Results: Six articles were used to review. The article discusses vitamin D deficiency as a causative factor for tuberculosis, the effectiveness of clinical treatment in a sanatorium using vitamin D and the use of sunlight as a treatment for tuberculosis in the days before the discovery of antibiotics.

Conclusion: Sun exposure has been shown to provide a clinical improvement in patients by providing comfort and improving moods that are unable to increase the elimination of bacteria in the lungs.
\end{abstract}

Keywords: Tuberculosis, TB, Vitamin D, Sunlight. 


\section{BACKGROUND}

Tuberculosis is an infectious disease caused by Mycobacterium. Tuberculosis which can attack various organs, especially the lungs (Kemenkes RI, 2016). The Record of Global Tuberculosis Report data in 2015 around 10.4 million new cases of tuberculosis occurred worldwide. Six countries with the highest new cases of tuberculosis were India, Indonesia, China, Nigeria, Pakistan, and South Africa. Indonesia is the 2nd ranks in the most TB sufferers after India and accounts for $45 \%$ of tuberculosis cases globally (WHO, 2016).

The Indonesian Tuberculosis Eradication Association (PPTI) describes TB regulation, the government includes TB services in hospitals as one of the conditions for accreditation. Therefore, there should a need for the latest breakthroughs in therapy to improve repair and healing (Buku Saku PPTI, 2010).

Sugiarti at al explained, before OAT therapy was found, nutrition was considered to be the main therapy against TB, for example, vitamin A and vitamin D. Since the discovery of OAT in the 1940s, the provision of nutrition was no longer plays an important role. It was also stated that vitamin D supplementation on OAT therapy has been shown to prove a significant clinical improvement (Sugiarti, 2018).

Research in Jakarta stated that the group with vitamin D supplementation had higher sputum conversion time and improved radiological picture (100\%) compared to the placebo group $(76.7 \%)$. The study concludes that vitamin D therapy is effective in addition to OAT therapy so vitamin D is suggested to be prophylactic for the environment that is in direct contact with patients because it is easy and the costs needed are quite affordable. One practical and efficient method is sun therapy or known as heliotherapy (Sugiarti, 2018).

Heliotherapy is a treatment with sunbathing under heat or sunlight that is believed to cure several infectious diseases. Hippocrates, over 2400 years ago, has said that the sun is very useful for dealing with various diseases. He has mentioned heliotherapy which means treatment with sunlight (Emokpae et al, 2016).

The sunlight that reaches the earth in eight minutes after traveling 15,000 million miles, is the most amazing germicide. Although today antibiotics are more used to deal with infections, healing with sunlight has been done, especially by people who are less able to buy modern medicine. Theoretically, bacteria exposed to ultraviolet light and direct sunlight will die within two hours. Infectious diseases that can be used in heliotherapy include sore throat, pneumonia, and leprosy (Emokpae et al, 2016).

The purpose of this article is to conduct a literature review of articles that research or discuss the effects of giving sunlight to tuberculosis patients.

\section{OBJECTIVE}

This study aimed at investigating the literature for of provision of sunlight in tuberculosis patients.

\section{METHODS}

\section{Search Strategy}

This Compilation Literature Review uses various databases by using searches in several electronic media such as Ebsco, ClinicalKey, Google Scholar, and ScienceDirect that have been conducted on December 2018 to January 2019. Searches are limited with articles published from 2016 to 2019 which are available in Indonesian and English. 


\section{Journal Of Nursing Practice}

http://thejnp.org

ISSN: 2614-3488 (print); 2614-3496 (online)

Vol.3 No.2. April 2020. Page.123-131

Some terms or keywords are combined in a search strategy to get the right articles such as using the terms "Sunlight Therapy", "Heliotherapy", "Sunlight Therapy" + "Tuberculosis" OR "Terapi Sinar Matahari", "Sunlight Therapy AND Tuberculosis"

\section{Article Selection Criteria}

The process of selecting articles included in this literature review must meet several criteria. Inclusion criteria are ; i) there's a paper, journal, or scientific article ; ii) Discussion of the profits and benefits of sunlight ; iii) The discussion focuses on tuberculosis patients or respiratory infections ; iv) Articles published from 2016 to 2019. Exclusion criteria are; i) Duplicate article; ii) Articles that are not published in scientific journals.

Articles that have been obtained meet the inclusion and exclusion criteria then analyzed, compared to each other, discussed and concluded. From these articles, 1 article discusses the trigger factors for tuberculosis where one was the lack of vitamin D originated from UV-B exposure and food sources, 1 article discusses the use of vitamin D, cod liver oil, sunlight and phototherapy for the treatment of tuberculosis in the era before the discovery of antibiotics, 1 article on the effectiveness of exposure to tuberculosis and respiratory infections, and 3 articles discuss the history of clinical medicine in a sanatorium using sunlight. The six articles obtained, two articles were original research, two journal review articles and two other scientific articles (Table 1).

\section{RESULTS}

The selection process from the Literature Review is shown in Figure 1. The results of the search strategy in the database received 132 articles but as many as 126 articles were issued because they did not comply the criteria. Six articles were obtained that matched the inclusion criteria and were approved.

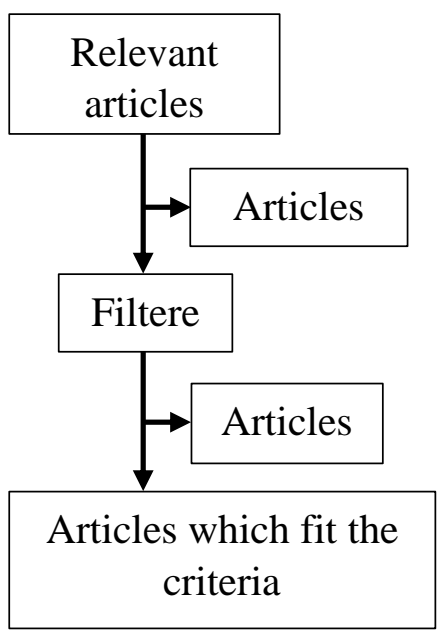

Figure 1. The results of the search strategy

\begin{tabular}{llllll}
\hline No & Author & Article Title & Writing purpose & Results & \\
\hline 1. & Boere et al & Solar Ultraviolet & Analyze the incidence of & $3.16 \%$ of & 100,000 \\
& (2017) & B Exposure and & tuberculosis and its causative & populations & in 154 \\
& English & Global Variation & factors in several countries & countries has occur the \\
\hline
\end{tabular}


Journal Of Nursing Practice

http://thejnp.org

ISSN: 2614-3488 (print); 2614-3496 (online)

Vol.3 No.2. April 2020. Page.123-131

\begin{tabular}{|c|c|c|c|c|}
\hline & Ecology Study & $\begin{array}{l}\text { in Tuberculosis } \\
\text { Incidence : An } \\
\text { Ekological } \\
\text { Analysis }\end{array}$ & & $\begin{array}{l}\text { new cases of tuberculosis } \\
\text { per year. Triggers for TB } \\
\text { cases are urbanization, } \\
\text { lack of UV-B exposure, } \\
\text { and nutrition. }\end{array}$ \\
\hline 2 & $\begin{array}{l}\text { Greenhalgh and } \\
\text { Butler } \\
(2017) \\
\text { English } \\
\text { Historical } \\
\text { descriptive }\end{array}$ & $\begin{array}{l}\text { Sanatoria } \\
\text { Revisited : } \\
\text { Sunlight and } \\
\text { Health }\end{array}$ & $\begin{array}{l}\text { Explore the historic of } \\
\text { treatment for tuberculosis } \\
\text { patients in sanatorium in the } \\
\text { 18th century }\end{array}$ & $\begin{array}{l}\text { Proper exposure, sunlight } \\
\text { can be useful for TB } \\
\text { treatment }\end{array}$ \\
\hline 3. & $\begin{array}{l}\text { Handono et al } \\
(2016) \\
\text { Indonesia } \\
\text { Case } \\
\text { Study research }\end{array}$ & $\begin{array}{l}\text { The Effect of } \\
\text { Sunlight to } \\
\text { Improve the } \\
\text { Effectiveness of } \\
\text { Airway Cleansing } \\
\text { in COPD Patients } \\
\text { in Selogiri health } \\
\text { center }\end{array}$ & $\begin{array}{l}\text { Knowing the influence of } \\
\text { sunlight on COPD patients. }\end{array}$ & $\begin{array}{l}\text { There is an effect of } \\
\text { sunlight on the airway } \\
\text { cleaning in COPD patients }\end{array}$ \\
\hline 4. & $\begin{array}{ll}\text { Martin. K } \\
(2016) & \\
\text { English } & \\
\text { A } & \text { Journal } \\
\text { Review } & \end{array}$ & $\begin{array}{l}\text { Modernism and } \\
\text { the } \\
\text { Medicalization of } \\
\text { Sunlight: D. H. } \\
\text { Lawrence, } \\
\text { Katherine } \\
\text { Mansfield, and } \\
\text { the Sun Cure }\end{array}$ & $\begin{array}{l}\text { Explore the perceptions of } \\
\text { patients having tuberculosis } \\
\text { treatment in the } 1920 \mathrm{~s}\end{array}$ & $\begin{array}{l}\text { Healing by sunbathing can } \\
\text { improve } \\
\text { conditions while forming } \\
\text { good emotions. }\end{array}$ \\
\hline 5. & $\begin{array}{l}\text { McCullough dan } \\
\text { Lehrer } \\
(2018) \\
\text { English } \\
\text { A } \\
\text { Comprehensive } \\
\text { Review }\end{array}$ & $\begin{array}{l}\text { Vitamin D, cod } \\
\text { liver oil, } \\
\text { sunshine, and } \\
\text { phototherapy: } \\
\text { Safe, effective } \\
\text { and forgotten } \\
\text { tools for treating } \\
\text { and curing } \\
\text { tuberculosis } \\
\text { infections - A } \\
\text { comprehensive } \\
\text { review }\end{array}$ & $\begin{array}{l}\text { Review reports before the } \\
\text { antibiotic era documented } \\
\text { clinical improvement in the } \\
\text { treatment of tuberculosis } \\
\text { using vitamin D, cod liver oil, } \\
\text { sunlight and phototherapy }\end{array}$ & $\begin{array}{l}\text { Vitamin D, cod liver oil, } \\
\text { sunlight and phototherapy } \\
\text { have a tremendous impact } \\
\text { on improving clinical cure } \\
\text { for tuberculosis at an } \\
\text { affordable cost. }\end{array}$ \\
\hline 6. & $\begin{array}{l}\text { Rushton. K } \\
\text { (2016) } \\
\text { English } \\
\text { Historical } \\
\text { descriptive }\end{array}$ & $\begin{array}{l}\text { The Records of } \\
\text { Stannington } \\
\text { Children's } \\
\text { Sanatorium: } \\
\text { Charting Half a } \\
\text { Century of } \\
\text { Tuberculosis Care }\end{array}$ & $\begin{array}{l}\text { Explore medical records of } \\
\text { treatment for tuberculosis on } \\
\text { Stannington children's in } \\
\text { sanatorium before the era of } \\
\text { antibiotics }\end{array}$ & $\begin{array}{l}\text { For } 46 \text { years children who } \\
\text { were cared for at } \\
\text { Stannington Sanatorium } \\
\text { by getting both artificial } \\
\text { and natural sunlight were } \\
\text { supported with adequate } \\
\text { nutrition and rest to help } \\
\text { fight disease }\end{array}$ \\
\hline
\end{tabular}




\section{DISCUSSION}

Tuberculosis is still a major health problem especially in developing countries like Indonesia. Patients who have been diagnosed with tuberculosis will undergo treatment for OAT (Anti-Tuberculosis Drugs) for six months. There needs to be a strong body system during treatment so prevention of complications and worsening conditions can be avoided (Sugiarti, 2018).

Long before the discovery of antibiotics, TB treatment was something terrible. Doctors in 18 th century used the pneumothorax method, which surgically knocked down or deflated a portion of the lungs to heal and thoracoplasty or chest autopsy that cut two to three ribs so that the lungs would have more space and were believed to cure patients, but unfortunately this has a negative impact, many patients experience complications until they die.

The treatment of tuberculosis is highlighted by heliotherapy (sunlight), which was popularized by Dr. Danish Niels Finsen in 1900s, many TB patients were accommodated in the Sanatorium for healing. In the 1940s TB treatment began to shift with the discovery of vitamin D. Independently vitamin D has been proven to cure infections without using penicillin simultaneously. Until 1947 the first anti-TB drug was discovered by Dr. Selman Waksman, this is changing all TB treatments that have been used and are now almost forgotten (McCullough, 2018). The main advantage of TB antibiotics is the ability to avoid prolonged hospitalization and does not require long maintenance costs (McCullough, 2015).

But along with the rapid development of pharmacology, we are faced with a crisis of antibiotic resistance. The emergence of new problems with the increasing prevalence of MDR TB and the development of TB-HIV disease, this requires more complex TB control and the need for breakthroughs in TB treatment so that it can improve and accelerate healing.

This article will review articles that discuss TB and Vitamin D, Sunlight Therapy, Sanatorium, and Emotional.

\section{Tuberculosis and Vitamin D}

The famous standard TB therapy is OAT therapy (anti-tuberculosis drugs). Before the discovery of OAT therapy, a therapy that had been used as the main therapy for TB was the provision of nutrients, namely vitamin A and vitamin D. The tuberculosis patients get treatment using oral vitamin D and injections that are injected intrapleural (Sugiarti, 2018).

In 1945, Dr. J.E.M. Wigley commented on the extraordinary thing about vitamin D's ability to cure TB: "I think we all agree on the results of this treatment, shown in these six cases, that many striking results that might be an update of time".

This was also acknowledged by Dr. In 1947 Michelson stated "the most important part, the recommended safe dose of vitamin D. Dowling and Thomas noted signs of mild intolerance in 8 of 38 patients except 1, all of whom were able to tolerate smaller doses without discomfort. Interestingly it is estimated that the need for vitamin D is needed high enough in the body. Daily vitamin D intake in doses exceeding 10,000 IU per day per pound of body weight, or higher than 20,000 IU per day per $\mathrm{kg}$ of body weight is considered necessary to prevent toxicity" (McCullough, 2018).

This is not much different from the research conducted by Lubis et al. In 2015, it provided complementary treatment of $100,000 \mathrm{iu}(2.5 \mathrm{mg})$ oral vitamin D in tuberculosis patients undergoing OAT treatment. The results showed that vitamin D improved clinical 


\section{Journal Of Nursing Practice}

http://thejnp.org

ISSN: 2614-3488 (print); 2614-3496 (online)

Vol.3 No.2. April 2020. Page.123-131

conditions as measured by sputum conversion times faster than patients who only received OAT treatment.

It is known that vitamin D deficiency occurs in patients affected by tuberculosis and is one of the risk factors for contracting this disease. The highest incidence of tuberculosis occurs in countries that experience socio-economic problems such as population density and malnutrition. Besides UV-B exposure and vitamin D status are additional determinants of tuberculosis. So it's important to have enough vitamin $\mathrm{D}$ in the body to prevent tuberculosis. Besides being obtained in the form of medicines, Vitamin D can also be obtained from sun exposure or food (Boere, 2017).

But for those who do not suffer from TB and as a precaution, a vitamin D diet is lower than a deficient TB patient. Recommendations from the US Medical Institute (600 IU per day for adults $\leq 70$ years and 800 IU per day for those who are $\geq 71$ years old) (Desai et al, 2012).

\section{Sanatorium}

Since 18th-century tuberculosis has become the leading cause of death worldwide. This is a highly contagious infectious disease and finding effective treatments to fight TB requires a lot of time. One of the first treatments that worked was to live in a sanatorium. The sanatorium is a medical facility that is used to treat long-term illnesses, especially tuberculosis patients. This sanatorium was very popular in Europe at the end of the 18th century, the sanatorium provides patients with fresh food and air especially because it was exposed to more sunlight (Greenhalgh, 2017).

The first sanatorium was opened in 1903 by Dr. Auguste Rollier (1874-1954) in the city of Leysin, in the Swiss Alps and a major supporter of sunlight therapy with Dr. Danish Niels Finsen (1860-1906). The first sanatorium was dedicated to caring for TB children and immediately began bringing TB patients from Europe (Greenhalgh, 2017).

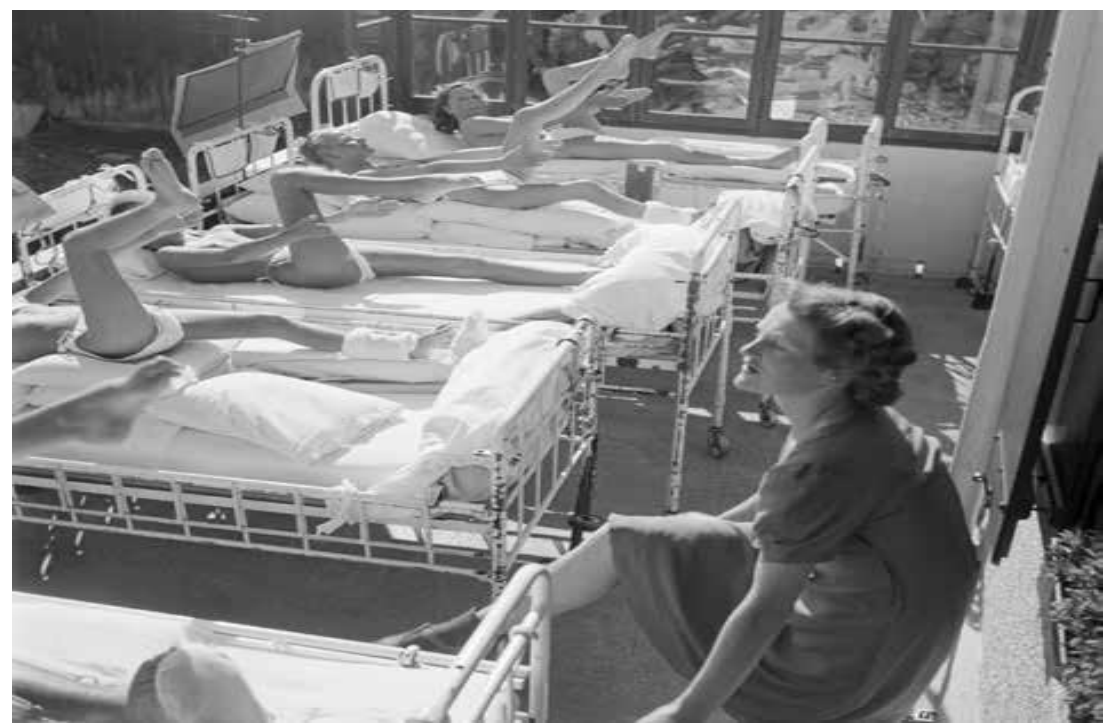

Figure 1. children basked in Sanatorium

Source: The Newsletter of the University of Virginia School of Nursing Eleanor Crowder Bjoring Center for Nursing Historical Inquiry. Volume 23, Issue 2 October 2015

Dr. Rollier revealed the main principle behind sun therapy is a combination of good food and rest to strengthen patients and enable them to fight and fight diseases better (11). From 
this information, the medical staff develops individual therapy plans that include sunbathing, high-fat diets, cereals, vegetables, and milk, plus planned exercise. Sunlight exposure to children and their reactions to cold air, temperature, and their physical activity are monitored carefully (Keeling, 2015).

In the early 1930s, the enthusiasm of doctors for heliotherapy and sanatorium began to decrease. Their success has not been proven in most medical facilities. Doctors agree that sunlight, fresh air, and nutritious food increase the general health of TB children, but do not cure them from tuberculosis. In 1953 Sanatorium was converted into a children's hospital before finally being completely closed in 1984 (Rushton, 2016).

\section{Sunlight Therapy}

The necessity of the sun to humans has been recognized for thousands of years. The ability to provide warm sunlight, a sense of well-being, and the ability to plant crops for food needs. In Ancient Egypt, Greece, India, and Rome recognized the extraordinary power of healing diseases using the sun, but in the early 18th century the medical profession began to develop and began to critically investigate whether the sun could heal. These pioneering medical doctors introduced it as sunlight therapy, which includes heliotherapy (sunlight) phototherapy (ultralight or artificial light). This therapy has proven effective in treating several forms of tuberculosis, a deadly disease that has infected humans for centuries (Keeling, 2015).

Actual data is presented in a report stating that patients suffering from TB differ from one country to another. In an ecological study that explored the relationship between UV-B exposure and the incidence of tuberculosis, it was shown that countries with high UV-B sun exposure had a TB incidence rate of $78 \%$ lower than countries in low exposure areas (Boere, 2017).

The lowest mortality rate is because TB is located in countries in the Rocky Mountains, which have more sun exposure, less rainfall, and are at much higher altitudes than in countries with high mortality. The conclusions put forward by experts are "extraordinary things where the low mortality rate in the Rocky Mountain country seems to be due to the uniqueness and favorable climate conditions, from the conclusion that climate affects TB treatment" (McCullough, 2018).

One example of improvement was a girl who was treated at the Sanatorium with peritoneal TB on May 1, 1925, when she was 8 years 11 months old. Dr. T.C. Hunter who handled it gave a detailed report on his case and his treatment with heliotherapy. The entry time is $115 \mathrm{~cm}$ and weighs only about $1.5 \mathrm{~kg}$. Immediately he received treatment for artificial sunlight by using a mercury vapor lamp for two minutes every day and rising slowly to five minutes, but his condition in a few months became worse and it was decided to stop artificial sunlight treatment. During the spring of 1926, it was possible to start the treatment of natural sunlight because of the amount of sunlight that was falling and at the request of patients with artificial sunlight treatment. Slowly his condition then began to improve (Rushton, 2016). The picture below was taken within two years.

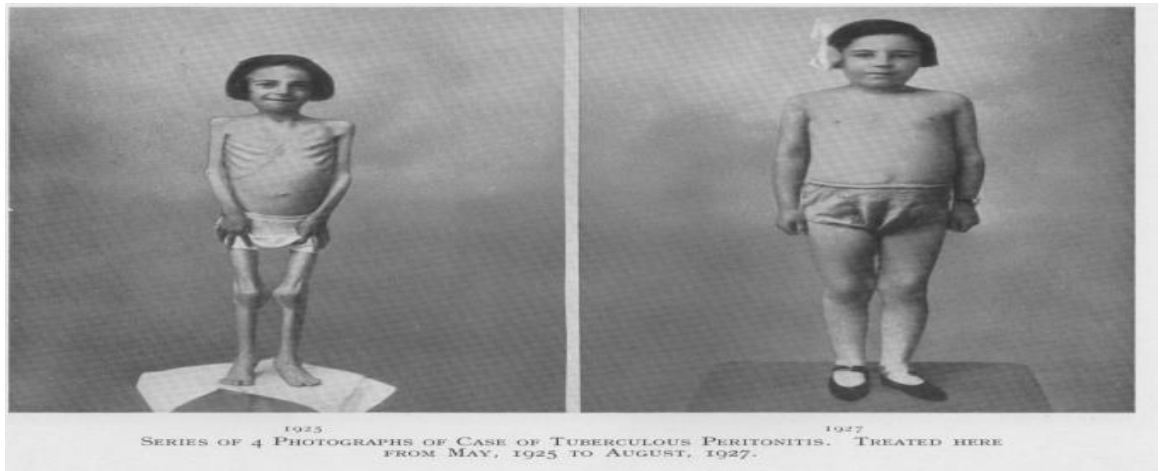


Figure 2. Source: Social History of Medicine Vol. 29, No. 4 pp. 829-839

Besides, sunlight therapy can also reduce tightness in patients with impaired airway cleaning. Research conducted by Handono in COPD patients decreased RR 24 times/minute from 26 times/minute. This sun therapy can be done each morning and evening or if the family feels short of breath because cold allergies appear. Duration of administration of sunlight therapy is about 15 to 20 minutes in a sitting position (Handono, 2016).

\section{Emotional Aspect}

Sun exposure also influences emotional changes. The research conducted by Handoko explained that COPD patients who have been given sunlight therapy experience a decrease in congestion and provide comfort and tranquility (Handono, 2016).

Katherine Mansfield, a writer who got a treatment program for sunbathing against tuberculosis, also wrote in her writing during treatment that sunrise and sunset provide a touch that affects not only her physical but also mood and this is an extraordinary natural tonic for the body.

As explained earlier that sunlight was very popular for the treatment of TB in the early 20th century. This perception of healing is not only intended for physical healing but also can provide feelings of pleasure in the feelings of patients when getting a treatment program (Martin, 2016).

This happens because when the skin is stimulated with UVB radiation, human skin produces beta-endorphin in response to exposure, this opioid peptide has the result of increasing feelings of well-being, improving the immune system, relieving pain, increasing relaxation, healing wounds, and being able to overcome the mild effects of depression to mood swings.

Skin also releases nitric oxide, a compound that can accelerate the amount of blood flow, stimulate vasodilation and reduce blood pressure. During active exposure to UVA, diastolic blood pressure drops by about $5 \mathrm{mmHg}$ and remains lower for 30 minutes after exposure. A decrease in diastolic blood pressure of $5 \mathrm{mmHg}$ reduces the risk of stroke by $34 \%$ and coronary heart disease by $21 \%$ (Baggerly, 2015).

\section{CONCLUSION}

Tuberculosis control is still a particular concern in Indonesia and even the world so that breakthroughs in TB treatment are needed so that they can improve and accelerate healing. In the pre-antibiotic years, medical staff popularized the treatment using sunlight to treat tuberculosis patients. This therapy provides clinical improvement to the patient and provides a calm sensation and improves mood even though it has not been able to eliminate the bacteria in the lungs until anti-TB drugs are found and this sunlight therapy is forgotten. The emergence of an antibiotic resistance crisis, we may have to rethink to revive drugs in a sanitarium in the 19th century as a companion treatment to accelerate the healing process by utilizing sunlight therapy, a diet high in vitamin $\mathrm{D}$ and a healthy lifestyle. 


\section{Journal Of Nursing Practice}

http://thejnp.org

ISSN: 2614-3488 (print); 2614-3496 (online)

Vol.3 No.2. April 2020. Page.123-131

\section{REFERENCES}

Baggerly, C. A., Cuomo, R. E., French, C. B., Garland, C. F., Gorham, E. D., Grant, W. B., ... \& Pittaway, M. (2015). Sunlight and vitamin D: necessary for public health. Journal of the American College of Nutrition, 34(4), 359-365.

https://doi.org/10.1080/07315724.2015.1039866

Boere, T. M., Visser, D. H., Van Furth, A. M., Lips, P., \& Cobelens, F. G. (2017). Solar ultraviolet B exposure and global variation in tuberculosis incidence: an ecological analysis. European Respiratory Journal, 49(6), 1601979. https://doi.org/10.1183/13993003.01979-2016

Desai, N. S., Tukvadze, N., Frediani, J. K., Kipiani, M., Sanikidze, E., Nichols, M. M., ... \& Seydafkan, S. (2012). Effects of sunlight and diet on vitamin D status of pulmonary tuberculosis patients in Tbilisi, Georgia. Nutrition, 28(4), 362-366. https://doi.org/10.1016/j.nut.2011.08.012

Emokpae, A. A., Mabogunje, C. A., Imam, Z. O., \& Olusanya, B. O. (2016). Heliotherapy for neonatal hyperbilirubinemia in Southwest, Nigeria: a baseline pre-intervention study. PloS one, 11(3). https://10.1371/journal.pone.0151375

Greenhalgh, I., \& Butler, A. R. (2017). Sanatoria revisited: sunlight and health. The journal of the Royal College of Physicians of Edinburgh, 47(3), 276-280. https://doi.org/10.4997/jrcpe.2017.314

Handono, N. P. (2018). pengaruh sinar matahari untuk meningkatkan efektifitas bersihan jalan nafas pada pasien PPOK. Jurnal KEPERAWATAN GSH, 5(2).

Keeling, A. W., \& Brodie, B. (2015). Historical Perspectives on Fresh Air, Sunshine, and Public Health. Windows in time, 23(2), 1-2.

Kemenkes, R. I. (2016). Infodatin: Tuberkulosis Temukan Obati Sampai Sembuh. Jakarta: Pusat Data dan Informasi.

Martin, K. (2016). Modernism and the Medicalization of Sunlight: D. H. Lawrence, Katherine Mansfield, and the Sun Cure. Modernism/modernity 23(2), 423-441. https://doi.org/10.1353/mod.2016.0028.

McCullough, P. J., \& Lehrer, D. S. (2018). Vitamin D, cod liver oil, sunshine, and phototherapy: Safe, effective and forgotten tools for treating and curing tuberculosis infections-A comprehensive review. The Journal of steroid biochemistry and molecular biology, 177, 21-29. https://doi.org/10.1016/j.jsbmb.2017.07.027

Perkumpulan Pemberantasan Tuberkulosis Indonesia. (2010). Buku Saku PPTI

Rushton, K. (2016). The Records of Stannington Children's Sanatorium: Charting Half a Century of Tuberculosis Care. Social History of Medicine, 29(4), 829-839. https://doi.org/10.1093/shm/hkw027

Sugiarti, S., Ramadhian, M. R., \& Carolia, N. (2018). Vitamin D sebagai Suplemen dalam Terapi Tuberkulosis Paru. Jurnal Majority, 7(2), 198-202

WHO-World Health Organization, \& WHO-World Health Organization. (2016). Global tuberculosis report 2016. http://apps.who.int/iris/bitstream/10665/250441/1/9789241565394-eng.pdf 